\title{
Identifying Essential Fisheries Competencies to Link to School Curriculum: Supporting Nez Perce Students' STEM Identity
}

\author{
Raymond A. Dixon, ${ }^{a}$ Karla Eitel, ${ }^{\mathrm{a}}$ Teresa Cohn, ${ }^{\mathrm{a}}$ Marcie Carter, ${ }^{\mathrm{a}}$ Kay Seven ${ }^{\mathrm{b}}$ \\ ${ }^{a}$ University of Idaho, ${ }^{b} \mathrm{Nez}$ Perce Tribal Education Department
}

\begin{abstract}
This study examined the process to identify required competencies for an entry-level position in the Nez Perce Tribe Department of Fisheries Resource Management located in the Pacific Northwest. The overall goal was to provide content for a pedagogical framework to support Nez Perce students in the development of their STEM identity and to consider careers in natural resources and fisheries. The DACUM process was used to analyze the job, Fisheries Technician. The process involved a focus group of six expert workers in the Department of Fisheries Resource Management and was led by a facilitator. The experts identified 48 competencies categorized as technical and professional for fisheries technician. Seven cultural competencies were also identified as important for the successful accomplishment of work and the quality of work life. Competencies will provide content for the middle and high school culture, science, and technology curriculums, and there is the potential to connect technical and professional competencies to a career and technical education microcredentialing system.
\end{abstract}

Keywords: fisheries education, culturally responsive teaching, DACUM, curriculum content, STEM identity

The development of future fisheries scientists and technicians from among the Nez Perce Tribe is of strategic importance to the restoration and maintenance of fisheries on the Nez Perce Reservation and within its extensive aboriginal territories, where tribal members maintain treaty rights for fishing, hunting, and gathering. To achieve this mission, it is necessary to place emphasis on developing the STEM identity of Nez Perce students so they can choose career pathways leading to jobs in the fisheries and natural resources industry. The high school curriculum for Native students must be integrated with fisheries competencies so students can develop these skills through the learning of science and technological concepts and procedures, as well as water governance practices specific to their Tribe. The teaching and learning of these competencies cannot be done at the exclusion of Nez Perce students' cultural values and ways of knowing and doing. Bang and Medin (2010) describe how Native students must learn to walk in two worlds

\footnotetext{
cc (i) $\odot$ Creative Commons CC-BY-NC-ND: This article is distributed under the terms of the Creative Commons Attribution 4.0 License (http://creativecommons.org/licenses/by/4.0/) which allows others to download your works and share them with others as long as they credit you, but they can't change them in any way or use them commercially.
} 
when it comes to Western science and their traditional epistemologies. Increasingly, there is an awareness that students' persistence in STEM, and other postsecondary programs, can be increased by creating learning environments that are not only inclusive but taught from a standpoint that legitimizes Indigenous epistemologies (Abrams et al., 2013). An acceptance of this has implications for how educational support systems can best plan for competencies that students in kindergarten through twelfth grade schools should acquire to function effectively in entry-level STEM positions in fisheries or to pursue degree programs in fisheries and natural resources.

The Nez Perce Tribe has identified specific cultural values that underpin its approach to fisheries management (S. Smith, personal communication, July 11, 2016). Without an understanding and appreciation of these cultural values, the job satisfaction and performance of employees will likely be less than optimal. Teaching and learning, therefore, should not only target technical and professional competencies but should also emphasize relevant cultural competencies, so Nez Perce students can make a proper transition to the workplace (Campinha-Bacote, 2000; Olavarria et al., 2005).

This study aimed to identify specific competencies for a technician position in the Department of Fisheries Resource Management (DFRM) of the Nez Perce Tribe, located in north central Idaho, and determine which of these competencies can potentially be integrated with the middle and high school curriculum in the Nez Perce school district. The study arose out of a National Science Foundation (NSF) Innovative Technology Experiences for Students and Teachers (ITEST) project in 2016 that focused, in part, on integrating emerging technologies in learning activities related to fisheries science. The researchers were guided by the following questions:

1. What are the technical and professional competencies for an entry-level fisheries technician?

2. What are the cultural competencies for an entry-level fisheries technician?

3. What tasks are more appropriate to provide content for the middle and high school curriculums?

\section{Context}

Nez Perce is a large northwest tribe in the United States of America with a culture tied closely to fishing (Nez Perce Tribe, 2018). Their "economy and culture evolved around northwest fish runs, and their persistence can be attributed in large part to the abundance of fish, which has serves as a primary food source, trade item, and cultural resource for thousands of years" (Polissar et al., 2016, p.3). Fishing historically included steelhead trout, several species of suckers, white fish, sturgeon, northern pikeminnow, lamprey, and some shellfish (freshwater clams) in addition to salmon. Their expansive aboriginal territory, to which they hold treaty rights, is rich in cold, clear, rivers and streams. Nez Perce people historically fish from the Snake, Salmon, Clearwater, Imnaha, Grand Ronde, Selway, Tucannon, Rapid Rivers and many other rivers within and outside their homeland and ceded territory (Nez Perce Tribe, 2018).

According to Polissar and associates (2016, p. 6), "The Nez Perce have lived through and experienced the extirpation of entire populations of fish by the blocking and 
altering of thousands of miles of rivers and streams as a result of dams... and the many other smaller projects." In addition, there are many anthropogenic and natural factors that are contributing to the decline of fish. Systematically tackling the problems that the river ecosystem face requires educating future scientists and technicians. This means that Nez Perce students must be motivated to pursue careers in natural resources and fisheries, and, besides having technical and scientific knowledge, they must understand the spiritual and cultural significance of fisheries to the Nez Perce people.

\section{Literature Review}

The literature points to several factors that affect the ecosystem of inland fish and their habitats. These range from pollution, alteration, and fragmentation of ecosystems to climate change (Dudgeon et al. 2006; Carpenter \& Folke, 2006). Many of these threats and challenges have been successfully addressed through regulations designed to restrict exploitation, improve habitat conservation, and control invasive species (Arlinghaus et al., 2013). While some threats caused by industrial pollution have decreased (Lynch et al., 2016), new challenges that have both biological and human dimensions need to be considered and addressed through engagements with other sectors and stakeholders. Chapman (1986) indicated that before the Columbia Basin was developed, the river was home to more than 200 anadromous stocks and returned seven to 30 million adult salmon and steelhead to the river annually. However, all anadromous stocks continued to decline despite bold efforts and millions of dollars spent on technological solutions such as hatcheries, screens at turbine intakes and irrigation diversions, and barging and trucking of juvenile fish around dams. At the turn of the century, nearly all existing stocks of anadromous salmonids in Idaho were listed under the Endangered Species Act (Williams et al., 1999). The decline of stock over the years has affected the way of life of Native groups such as the Nez Perce, and tackling this problem in a significant way involves educating more fisheries scientists and technicians.

Fisheries Education. Fisher (2011) expressed concern about the misalignment that exists between employment opportunities and the type of fisheries curriculums. Specifically, these concerns were driven by societal changes related to an older retiring workforce and changing demographics. Concerns also include less funding for natural resource conservation, generational changes, and curricular shifts away from field-based approaches to traditional fisheries and aquatic science and management. These shifts reinforce the need for a reevaluation of how the next generation of fisheries professionals are educated to meet the challenges of the changing environment and the needs of the workforce.

In a study by McMullin and associates (2016) to determine how well the next generation of fisheries professionals are prepared, online surveys were sent to members of the American Fisheries Society (response rate was 14\%, $n=1,490$ ). Their findings indicated:

employers rated oral and written communication skills, and critical thinking skills as the most important contributors to the career success of entry-level employees. 
Communication courses and fisheries-specific topics were rated highest in importance among academic topics, whereas aquaculture, aquatic entomology/invertebrate zoology, and physical sciences were rated lowest in importance. (p. 441)

Respondents suggested professional societies should not be the major decider of essential skills for professionals at the entry-level, but this should be decided by employers and universities, with professional societies playing a lesser role. They further indicated that employers should have equal or more responsibility than universities to establish what constitutes effective communication with non-technical audiences, practical field skills, and working in teams.

According to Hansen (2016), young professionals in fisheries opined their experiences outside of the classroom contributed significantly to their early career success. These experiences in the field help in sharpening their problem-solving, critical thinking, and personnel management skills. They also provided hands-on experience with fisheries and ecological procedures. In addition, recent graduates suggested the "limited time in school would be best spent honing technical skills that are applicable across a range of disciplines (e.g., statistics, programming, database management), improving communication and critical thinking skills, and gaining experience outside the classroom" (p. 476).

While discourses about the preparation of future professionals in fisheries tend to focus primarily on university programs at the undergraduate and graduate levels, the fact that technician-level jobs such as fisheries, habitat, laboratory, and systems maintenance technicians are also required for the fisheries industry suggests additional attention needs to be focused on strategies to address the talent pipeline for these positions. Such a strategy would be prudent since some students do not choose to go on to college immediately after graduating high school. Having the required competencies to acquire technician-level jobs in fisheries may motivate students to embark on career pathways that can lead to the attainment of degrees to work at the professional level in the industry.

The Nez Perce tribal fisheries recognize the need to motivate more students to pursue careers in fisheries. They have revealed that an aging workforce will need to be replaced in the coming years in many of the Tribe's key STEM-related positions (S. Smith, personal communication, July 11, 2016). New and emerging technologies are also influencing the management practices in fisheries. Therefore, students need to acquire knowledge about these technologies. Because of the high economic, social, and spiritual significance, as well as the sense of place and heritage (Chan et al., 2012) of fisheries to the Nez Perce Tribe, initiatives to develop the next generation of fisheries technicians and scientists from among the Tribe are integral. This requires strengthening the STEM curriculum for Nez Perce students at the high and middle school levels. Mainstream curriculum, however, emphasizes Western ways of scientific knowing and doing, without giving much relevance to indigenous epistemology (Gollnick \& Chinn, 2013). By contrast, studies suggest that culture and identity play an important role in supporting students' successful learning and navigation of STEM career pathways (Brown, 2004; Chang et al., 2014; Chemers et al., 2011). There is also growing awareness that students' persistence in STEM is improved by creating learning environments that are not only 
inclusive but are taught from a standpoint that draws upon and integrates indigenous epistemologies (Abrams et al., 2013; Bang \& Medin, 2010). In general, there is evidence that culturally responsive pedagogies foster academic achievement, engagement (Christianakis, 2011; Rodriguez et al., 2004), and a sense of critical consciousness (Epstein et al., 2011; Martell, 2013).

\section{Theoretical Framework}

Two processes were employed to frame this study, Job Analysis and DACUM. Job analysis frequently precedes the steps to restructure jobs to promote efficiency, create job specification, and determine training needs (Morganson et al., 2009). It is a methodical process whereby judgments are made, and data collected to document the requirements of a job and the work performed (Brannick \& Levine 2002; Clifford, 1994). The result is a description of required duties, responsibilities, attitudes, and skills for the job (Morganson et al., 2009). Job analysis can provide inputs to determine curriculum content in schools and organizations (Finch \& Crunkilton, 1999). Of the two main types of job analysis, the worker-oriented approach targets information regarding the competencies required to perform a job, while the job-oriented approach targets the job itself and the tasks performed by the worker (Cucina et al., 2013). Processes used to perform job analysis range from individual to focus groups and strategies used to collect data include observations, surveys, and critical incidents (Chang \& Kleiner, 2002; Shetterly \& Krishriamoorthy, 2008).

The DACUM (Developing $\underline{\text { A }}$ Curriculum) process uses five to 12 workers who are considered to be expert by their employers to systematically identify competencies related to a particular job for curriculum content (Finch \& Crunkilton, 1999; Norton, 1997). Using expert employees from specific industries to perform a job analysis of their work can result in highly reliable competency profile. The DACUM process is based on three suppositions: (1) highly proficient workers can better describe the elements of their job; (2) a job can be broken down into the tasks that successful workers in that job perform; and (3) the specific knowledge, skills, attitudes, and tools required by workers to correctly perform their jobs can also be described (Norton, 1997). The competency profile sheet that is generated from the process presents the skills of a job or an entire occupation, reducing the chance of treating one element of the job or occupation separately from others (Finch \& Crunkilton, 1999). A trained facilitator guides the expert workers through a process of brainstorming, synergy, consensus building, and validation to develop the competency profile for the position.

\section{Method}

This qualitative research was conducted through a series of inclusive methods designed to draw on the tribe's expertise in fisheries. The groupware process, DACUM, was used to analyze the job of an entry-level fisheries technician position at the Nez Perce DFRM. 
Participants. The Nez Perce Tribe DFRM nominated six expert fisheries professionals to be resource persons for the DACUM workshop. Four had the job title, fisheries technician; one, professional scientist; and one, data technician. All participants were members of the Nez Perce Tribe. The purpose of the job analysis was explained to the participants by letter prior to the workshop.

Procedure. The workshop was conducted over two days. In addition to the participants, three members from the management and supervisory staff were present as observers. The following delineates the activities on the first day.

1. Orientation to the DACUM process by the facilitator and explanation of code of conduct for workshop.

2. Explanation of terms used on DACUM chart.

3. Development of organizational chart illustrating the reporting function of a fisheries technician.

4. Initial brainstorming of daily duties of a fisheries technician.

5. Identification of duties and writing of appropriate duty statements.

6. Identification of tasks for each duty and writing of appropriate task statements.

On the second day, the panel worked with the facilitator to:

1. Confirm there were no missing duties and tasks.

2. Sequence the tasks and duties identified on the first day by order of importance or logic.

3. Identify general knowledge and skills, attitudes, tools, equipment, supplies and materials, future trends/issues, and important acronyms.

The information obtained from the panel of experts was then entered in a document referred to as a competency profile chart (Norton, 1997). To ensure trustworthiness, each participant member-checked a draft of the competency profile chart about a week later to ensure the duty and task statements accurately reflected what was agreed by consensus during the workshop. Identified errors and recommended corrections were sent out to the group for final checking. The chart was sent to two other experts in fisheries who were not a part of the DACUM panel, to validate whether the competencies accurately represent the job of an entry-level fisheries technician. These two experts unanimously agreed the competency profile accurately reflected the job of an entry-level fisheries technician.

\section{Results}

Research Question 1: What are the technical and professional competencies for an entrylevel fisheries technician?

The experts identified 48 competencies that are categorized as technical and professional for fisheries technician. Theses competencies fall under six main areas 
referred to as duties. Table 1 lists these competencies. A total of 24 technical competencies and 24 professional competencies were identified.

Table 1. Technical and Professional Competencies Related to Job Duties

\begin{tabular}{|c|c|}
\hline \multicolumn{2}{|c|}{ Entry-level Fisheries Technician } \\
\hline $\begin{array}{l}\text { Technical } \\
\text { Understand Fish and Ecosystem } \\
\text { - Identify Different Fish Species* } \\
\text { - Identify Adult Fish Gender* } \\
\text { - Identify Invasive Plant Species* } \\
\text { - Identify Native Species* } \\
\text { - Perform Habitat Improvements* } \\
\text { - Describe Fish Anatomy* } \\
\text { - Describe Targeted Species Life Cycle* } \\
\text { - Identify Major Waterbodies and } \\
\text { Landmarks* }\end{array}$ & $\begin{array}{l}\text { Professional } \\
\text { Perform Basic Job Functions } \\
\text { - Perform First Aid/CPR* } \\
\text { - Maintain Insurable Driving Record } \\
\text { - } \text { Comply with Drug-free Work Policies } \\
\text { - Maintain Good Physical Fitness* } \\
\text { - } \text { - Fear Appropriate Field Gears Safety Requirements* } \\
\text { - Collect Fisheries Data* } \\
\text { - } \quad \text { Perform Fisheries Function with } \\
\quad \text { Minimum Supervision }\end{array}$ \\
\hline $\begin{array}{l}\text { Use Electronic Equipment } \\
\text { - Operate Computer* } \\
\text { - } \quad \text { Operate Hand-held Device* } \\
\text { - } \text { Operate GPS* } \\
\text { - } \quad \text { Handle Two-way Radios* } \\
\text { - } \text { Operate Metal Detector* } \\
\text { - Operate PIT tag Reader } \\
\text { - } \quad \text { Operate Satellite Phone } \\
\text { - } \quad \text { Read Weight Scales* }\end{array}$ & $\begin{array}{l}\text { Act Professionally } \\
\text { - Use Common Sense } \\
\text { - } \text { Give Appropriate Feedback* } \\
\text { - } \text { Apply Time Management Skills* } \\
\text { - Practice Self-motivation* } \\
\text { - } \text { Maintain Positive Attitude* } \\
\text { - } \text { Dress Appropriately* } \\
\text { - Practice Teamwork* } \\
\text { - } \text { Represent the Tribe Respectfully* }\end{array}$ \\
\hline $\begin{array}{l}\text { Use Mechanical Equipment } \\
\text { - Operate Motor Vehicle* } \\
\text { - Operate Water Pump* } \\
\text { - Operate Chainsaw } \\
\text { - Operate Gas/Propane Generator } \\
\text { - Operate Auger } \\
\text { - Operate Lawnmower/Weed Eater* } \\
\text { - Operate Pressure Washers* } \\
\text { - Operate Weirs and Screw Traps }\end{array}$ & $\begin{array}{l}\text { Communicate with Peers and Supervisors } \\
\text { - Apply Human Relation Skills } \\
\text { - } \text { Maintain Daily Diaries } \\
\text { - Apply Proper Protocols of Two-way } \\
\text { - } \text { Update Work Schedules } \\
\text { - Seek Clarification of Tasks and Duties* } \\
\text { - Interpret Supervisor's Instructions } \\
\text { - Communicate Respectfully with } \\
\text { - Supervisors } \\
\text { - Interpret Chain of Command }\end{array}$ \\
\hline
\end{tabular}


Journal of Research in Technical Careers

Research Question 2: What are the cultural competencies for an entry-level fisheries technician?

The panel of experts identified seven cultural competencies that are relevant to working at the Nez Perce DFRM. These cultural competencies are deemed integral for the successful accomplishment of work and the quality of work life. These are:

1. Participate in Nez Perce Culture Training

2. Understand Nez Perce History

3. Appreciate Nez Perce Language

4. Understand Nez Perce Governance

5. Understand Nez Perce's Treaties

6. Connect Duties to Cultural Significance

7. Appreciate Nez Perce Humor

Research Question 3: What tasks are more appropriate for content for the middle and high school curriculums?

Of the total 55 tasks identified by the experts, 37 were viewed as competencies that can provide content to be integrated at various levels of the middle and high school curriculum. Of note are the experts' opinion that all competencies associated with job functions, understanding fish and ecosystem, and knowledge of Nez Perce culture, should be infused and taught in the middle and high school curriculum. The remaining technical and professional duties have varying competencies the experts believed can be taught at various levels of the high school curriculum. In Table 1 the tasks with an asterisk represent competencies that experts believed should be taught in the middle and/or high school curriculum. Content analysis will need to be conducted to determine what are the appropriate grade levels to teach each competency.

\section{Discussion and Conclusion}

While supporting the development of Native students' STEM identity is important to address tribal workforce needs, the process cannot be uncoupled from the value system of Indigenous people, but must embrace their history, culture, spirituality, humor, and epistemologies. Cultural competency brings added value to the workplace because it facilitates the creation of inclusive spaces, and these spaces in turn promote active listening, flexibility, respect, innovation, and readiness to accommodate diverse needs (Turnbull et al., 2010). A culturally competent worker is expected to possess strong personal identity, understand and appreciate variations in the affective dynamics of culture, communicate in the language of the target groups when necessary, adhere to sanctioned behaviors where applicable, and maintain an active social relationship with cultural groups (Johnson et al., 2006; Ghosh, 2013). The competencies identified by the panel of experts show consistency with most of the foregoing, and they demonstrate the intentionality of having new workers developing appropriate cultural competencies that will lead to successful relationships and productivity in fisheries.

Some competency profiles may report cultural competencies as enabling attitudes for a specific job, and these are normally identified under "Worker Attitude" of the 
DACUM competency profile chart. However, in this DACUM process the expert panel asserted that Knowledge of $\mathrm{Nez}$ Culture must be listed as a duty, referencing its significance in the day-to-day job function in fisheries. The competencies associated with these duties will be integrated at various levels of the middle and high school curriculum. New workers who are not of Native background are also expected to develop an understanding of Nez Perce culture, which would include Nez Perce history, governance, treaty rights, and even their humor. This is implied in the task Participate in Nez Perce Culture Training.

The competency profile will provide content that will be integrated in the culture, technology, and science curriculums. A pedagogical model for infusing this content in the curriculum is the Traditional Ecological Knowledge or Indigenous Knowledge based approach, a form of culturally responsive teaching for the infusion of knowledge, skills, and attitudes into the school's curriculum. This framework is used successfully in STEM curriculum design for Native programs (Kimmerer, 2012). Traditional Ecological Knowledge represents beliefs, authentic ways of doing things, knowledge, and procedures that is cumulative and references the relationship of living beings with one another and with their environment. It validates native students' cultural knowledge and offers students psychological and intellectual liberation in the context of learning STEM, connecting meaningfulness between home and school experiences, academic abstractions, and sociocultural realities (Berkes et al., 2000; Gay, 2000; Howard, 2012).

Implications for Career and Technical Education. The competency profile also creates the opportunity to link the high school curriculum to the career and technical education (CTE) system. The professional and technical competencies identified can become the basis for the development of electronic "badges" that lead to the acquisition of microcredentials by high school students as they develop proficiency in the various

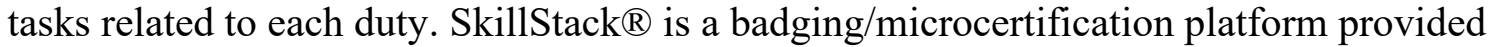
by the Idaho Division of Career and Technical Education (ICTE) that allows Idaho educators to validate the skills in which their students demonstrate proficiency, leading to industry-relevant badges. Microcredentials are awarded after competency is demonstrated in a specific skill area. A series of badges represents progression towards a microcredential. According to Elkordy (2012), digital microcredentialing has emerged as a process that uses digital badges to clarify, validate, describe and define the skills, knowledge, and capabilities learners have acquired (see also Elliott, Clayton, \& Iwata, 2014; Gibson et al., 2015; Goligoski, 2012; Walshe, 2014).

As Native students develop their STEM identity and become comfortable with their cultural identity, the more capable they will be in transitioning to work-life in fisheries, and the more confident they will be in their perception of themselves as developing scientists. The competencies identified reflect what is relevant for the entrylevel fisheries technician position at the Nez Perce Tribe DFRM offers a valuable content map for Nez Perce school curriculum. While all the competencies identified are valid, they cannot be generalized to all fisheries departments within and beyond the state. Critical insight, however, can be gained if the chart is used to determine entry-level job requirements in other fisheries departments and content for school curriculum. Further 
Journal of Research in Technical Careers

research can provide answers to whether similar competency charts used in the natural resource and fisheries industry of other Native tribes furnish similar technical, professional, and cultural competencies. In addition, using these charts to determine content for the curriculum increases the crosscutting of STEM and cultural engagement in the curriculum and the number of students showing interest in natural resources and fisheries careers.

Note: This material is based upon work supported by the National Science Foundation under Grant No. 1513349. Any opinions, findings, and conclusions or recommendations expressed in this material are those of the authors and do not necessarily reflect the views of the National Science Foundation.

\section{References}

Abrams, E., Taylor, P. C., \& Guo, C. J. (2013). Contextualizing culturally relevant science and mathematics teaching for indigenous learning. International Journal of Science and Mathematics Education, 11(1), 1-21. https://doi.org/10.1007/s10763-012-9388-2

Arlinghaus, R., Cooke, S. J., \& Potts, W. (2013). Towards resilient recreational fisheries on a global scale through improved understanding of fish and fisher behavior. Fisheries Management and Ecology 20(2-3), 91-98. https://doi.org/10.1111/fme.12027

Bang, M., \& Medin, D. (2010). Cultural processes in science education: Supporting the navigation of multiple epistemologies. Science Education, 94(6), 1008-1026. https://doi.org/10.1002/sce.20392

Berkes, F., Colding, J., \& Folke, C. (2000). Rediscovery of traditional ecological knowledge as adaptive management. Ecological Applications, 10, 1251-1262. https://doi.org/10.1890/1051-0761(2000)010[1251:ROTEKA]2.0.CO;2

Brannick, M. T., \& Levine, E. L. (2002). Job analysis: Methods, research, and applications. Sage.

Brown, B. (2004). Discursive identity: Assimilation into the culture of science and its implications for minority students. Journal of Research in Science Teaching, 41(8), 810834. https://doi.org/10.1002/tea.20228

Campinha-Bacote, J. (2000). The process of cultural competence in the delivery of healthcare services: A model of care. Journal of Transcultural Nursing, 13, 181-184. https://doi.org/10.1177/10459602013003003

Carpenter, S. R., \& Folke, C. (2006). Ecology for transformation. Trends in Ecology and Evolution, 21, 309-315. https://doi.org/10.1016/j.tree.2006.02.007

Chan, K. M., Satterfield, T., \& Goldstein, J. (2012). Rethinking ecosystem services to better address and navigate cultural values. Ecological Economics 74, 8-18. https://10.1016/j.ecolecon.2011.11.011

Chang, I. W., \& Kleiner, B. H. (2002). How to conduct job analysis effectively. Management Research, 25(3), 73-82.

Chang, M. L., Sharkness, J., Hurtado, S., \& Newman, C. B. (2014). What matters in college for retaining aspiring scientists and engineers from underrepresented racial groups. Journal of Research in Science Teaching, 51(5), 555-580. https://doi.org/10.1002/tea.21 146

Chapman, D. W. (1986). Salmon and steelhead abundance in the Columbia River in the nineteenth century. Transactions of the American Fisheries Society, 115, 662-670. https://doi.org/10.1577/1548-8659(1986)115<662:SASAIT>2.0.CO;2 
Chemers, M. M., Zurbriggen, E. L., Syed, M., Goza, B. K., \& Bearman, S. (2011). The role of efficacy and identity in science career commitment among underrepresented minority students. Journal of Social Issues, 67(3), 469-491. https://doi.org/10.1111/j.15404560.2011.01710.x

Christianakis, M. (2011). Hybrid texts: Fifth graders, rap music, and writing. Urban Education, 46, 1131-1168. https://doi.org/10.1177/0042085911400326

Clifford, J. P. (1994). Job analysis: Why do it, and how it should be done. Public Personnel Management, 23(2), 321-340. https://doi.org/10.1177/009102609402300211

Cucina, J. M., Martin, N. R., Vasilopoulos, N. L., \& Thibodeuax, H. F. (2013). Self-serving bias effects on job analysis ratings. The Journal of Psychology, 146 (5), 511-531.

Dudgeon, D., Arthington, A. H., Gessner, M. O., Kawabata, Z., Knowler, D. J., Lévêque, C., Naiman, R. J., Prieur-Richard, A., Soto, D., Stiassny, M. L. J., \& Sullivan, C. A. (2006). Freshwater biodiversity: Importance, threats, status, and conservation challenges. Biological Reviews, 81(2), 163-182. https://doi.org/10.1017/S1464793105006950

Elliott, R., Clayton, J., \& Iwata, J. (2014). Exploring the use of micro-credentialing and digital badges in learning environments to encourage motivation to learn and achieve. In B. Hegarty, J. McDonald, \& S. K. Loke (Eds.), Rhetoric and reality: Critical perspectives on educational technology. Proceedings Ascilite Dunedin 2014 (pp. 703-707). http://researcharchive.wintec.ac.nz/3546/1/276-Elliott.pdf

Elkordy, A. (2012). The future is now: Unpacking digital badging \& micro-credentialing for $K$ 20 educators. http://ncpeapublications.blogspot.co.nz/2012/10/the-future-is-nowunpacking-digital.html

Epstein, T., Mayorga, E., \& Nelson, J. (2011). Teaching about race in an urban history class: The effects of culturally responsive teaching. Journal of Social Studies Research, 35(1), 2-21.

Finch, C. R., \& Crunkilton, J. R. (1999). Curriculum development in technical and vocational education (5th ed.). Allen and Bacon.

Fisher, B. (2011). The changing fisheries education and employment connection. Fisheries, 36(12), 581, 622. https://doi.org/10.1080/03632415.2011.640225

Gay, G. (2000). Culturally responsive teaching: Theory, research, \& practice. Teachers College Press.

Ghosh, A. (2013). Interpersonal cross-cultural contact: Exploring the role of cultural encounters as antecedent to cultural competence at workplace. Management and Labour Studies 38(1\&2), 81-101. https://doi.org/10.1177/0258042X13491355

Gibson, D., Ostashewski, N., Flintoff, K., Grant, S., \& Knight, E. (2015, June). Digital badges in education. Education and Information Technologies, 20(2), 403-410. http://doi.org/10.1007/s10639-013-9291-7

Goligoski, E. (2012). Motivating the learner: Mozilla's Open Badges program. Access to Knowledge: A Course Journal, 4(1). http://ojs.stanford.edu/ojs/index.php/a2k/article/view/381

Gollnick, D. M., \& Chin, P. C. (2013). Multicultural education in a pluralistic society (9th ed.). Teachers College Press.

Hansen, G. J. A. (2016, August). If I knew then what I know now: Advice for fisheries students from recent fisheries graduates. Fisheries, 41(8), 475-476. https://doi.org/10.1080/03632415.2016.1199229

Howard, T. C. (2012). Culturally responsive pedagogy. In J. Banks (Ed.), Encyclopedia of Diversity in Education (Vol. 1, pp. 549-552). Sage.

Johnson, J. P., Lenartowicz, T., \& Apud, S. (2006). Cross-cultural competence in international business: Toward a definition and a model. Journal of International Business Studies, 37(4), 525-543. https://doi.org/10.1057/palgrave.jibs.8400205 
Kimmerer, R. W. (2012). Searching for synergy: Integrating traditional and scientific ecological knowledge in environmental science education. Journal of Environmental Studies and Sciences, 2, 317-323.https://doi.org/10.1007/s13412-012-0091-y

Lynch, A. J., Cooke, S. J., Beard Jr., T. D., Kao, Y., Lorenzen, K., Song, A. M., Allen, M. S., Basher, Z., Bunnel, D. B., Camp, E. V., Cowx, I. G., Freedman, J. A., Nguyen, V. M., Nohner, J. K., Rogers, M. W., Sliders, Z. A., Taylor, W. W., \& Youn, S. (2016). Grand challenges in the management and conservation of North American inland fishes and fisheries. Fisheries, 42(2), 115-124. https://doi.org/10.1080/03632415.2017.1259945

Martell, C. C. (2013). Race and histories: Examining culturally relevant teaching in the U.S. history classroom. Theory \& Research in Social Education, 41, 65-88.

McMullin, S. L., DiCenzo, V., Essig, R., Bonds, C., DeBruyne, R. L., Kaemingk, M. A., Mather, M. E., Myrick, C., Phelps, Q. E., Sutton, T. M., \& Triplett, J. R. (2016). Are we preparing the next generation of fisheries professionals to succeed in their careers? A survey of AFS members. Fisheries, 41(8), 436-449. https://doi.org/10.1080/03632415.2016.1199218

Morganson, V. J., Major, D. A., \& Bauer, K. N. (2009). Work-life job analysis: Applying a classic tool to address contemporary issues. The Psychologist-Manager Journal,12, $252-$ 274. https://doi.org/10.1080/10887150903316305

Nez Perce Tribe. (2018). Department of Fisheries Resources Management. http://www.nptfisheries.org/

Norton, R. E. (1997). The DACUM handbook. The Ohio State University Center on Education and Training for Employment.

Olavarria, M., Beaulac, J., Bélanger, A., Young, M., \& Aubry, T. (2005). Standards of organizational cultural competence for community health and social service organizations: Report for Centretown Community Health Centre. University of Ottawa, Centre for Research on Community Services.

Polissar, N. L., Salisbury, A., Ridolfi, C., Callahan, K., Neradilek, M., Hippe, D. S., Beckley, W. H. (2016). Heritage Fish Consumption Rates of the Nez Perce Tribe Final Report. www.epa.gov/sites/production/files/2017-01/documents/heritage-fish-consumption-ratesnez-perce-dec2016.pdf

Rodriguez, J. L., Jones, E. B., Pang, V. O., \& Park, C. D. (2004). Promoting academic achievement and identity development among diverse high school students. High School Journal, 87(3), 44-53.

Shetterly, D. R., \& Krishriamoorthy, A. (2008). Job characteristics of officers and agents: Results of a national job analysis. Public Personnel Management, 37(1), 111-131. https://doi.org/10.1177/009102600803700108

Turnbull, H., Greenwood, R., Tworoger, L., \& Golden, C. (2010). Skill deficiencies in diversity and inclusion in organizations: Developing an inclusion skills measurement. Academy of Strategic Management Journal, 9(1), 1-14.

Walshe, S. J. (2014). Digital badges finding use in education and across industries. http://www.extremenetworks.com/digital-badges-finding-use-in-education-and-acrossindustries/

Williams, R. N., Bisson, P. A., Bottom, D. L., Calvin, L. D., Coutant, C. C., Erho Jr, M. W., Frissel, C. A., Lichatowich, J. A., Liss, W. J., McConnaha, W. E., Mundy, P. R., Stanford, J. A., \& Whitney, R. R. (1999). Return to the river: Scientific issues in the restoration of salmonid fishes in the Columbia River. Fisheries, 24(3), 10-19. https://doi.org/10.1577/1548-8446(1999)024<0010:RTTRSI >2.0.CO;2 